\title{
The method of strengthening character education values for students in industrial revolution 4.0 era
}

\author{
Luluk Ifadah \\ STAINU Temanggung Central Java \\ bundaqotrunnada@gmail.com
}

DOI: $10.18326 /$ attarbiyah.v4i2.144- 166

\begin{abstract}
This study aims at providing an understanding of the Method of Strengthening the character education value for students in the Industrial revolution 4.0 era. In writing this study seeks to present methods that are relevant for strengthening the value of character education in students in Industrial revolution 4.0 era. The results showed that the method of strengthening the value of character education for students in the Industrial Revolution 4.0 era included: a) Exemplary Method, b) Pilot Method, c) Habituation Method, d) Repetition Method, e) Training Method, f) Motivation Method. The challenges are the readiness of educational institutions and educational resources, the readiness of families, the still weak control and support of elements of society, and the shift in the community's paradigm from productivity to consumptive. Then opportunities that can be exploited are self-development faster, opportunities to become innovators in every field of expertise, students from all walks of life have the same opportunity in strengthening competitiveness in the global era.
\end{abstract}

Keywords: strengthening values, character education, students, industrial Revolution 4.0 
Attarbiyah, Journal of Islamic Culture and Education

https://www.attarbiyah.iainsalatiga.ac.id/index.php/attarbiyah/

\section{INTRODUCTION}

Basically education is a process and outcome, as an educational process is defined as an activity of human interaction with the environment and as a change in education is interpreted as a change in the results of human interaction with the environment (Rulam Ahmadi, 2016: 31). Through human education to change themselves for the better and benefit themselves or others.

At present the development of technological flows is like two sides of a coin that provides two aspects of both positive and negative consequences, especially for students who must struggle with the era of globalization without having clear filtration and foundations. The world is now entering the Industrial revolution 4.0 era which is marked by the massive development of digital economic patterns, artificial intelligence, big data, robotic, and finally the world is changing much faster (Zaki Mubarak, 2018: 5) .

The industrial revolution 4.0 has a domino effect on all sides including the world of education. After the heyday of machines, electricity and technology has been completed, it's time for technology to be reduced to an instrument for all components of life. This technology is an important player in human life, and even tends to control human life. Education as a living system faces various problems in integrating the Industrial revolution 4.0 era with the ongoing education system.

In the modern formal education process the role of teachers today has experienced a shift, namely learning is no longer centered on the teacher ( teacher centered) but more centered on students ( student centered), the teacher only acts as a facilitator of students. In student-centered learning, the teacher 
consciously places more attention on students' involvement, initiative, and social interaction ( Fathurrohman, 2015: 115).

Challenges in the world of education today are part of the relevance of the presence of the Law on the National Education System Number 20 of 2003 Article 3 states that national education functions to develop and shape the dignified character and civilization of the nation in the context of intellectual life of the nation. It aims to develop the potential of students to become human beings who believe and fear God Almighty, have noble, healthy, knowledgeable, capable, creative, independent, and become citizens who are democratic and responsible in all things (Damayanti, 2014: 9).

The formulation of the goal of national education becomes the foundation in character education which is expected to be able to deliver students to not only know what should be done but also understand why it is done, so that in the Industrial Revolution 4.0 era students should still be able to behave in accordance with their character education.

Strengthening the character education of students in the Industrial revolution 4.0 era requires a long, continuous and integrative education process. Because the progress of the era like anything in the future still requires a strong foundation of character. The issue of student character is a very urgent matter for the development and progress of the nation, so here the author is interested in researching on Strengthening Character Education values for students in the Industrial Revolution 4.0 Era.

\section{METHODS}

The data collection method in this research uses literature study. In this stage, the researcher tries to select data (books) that are relevant to the Method 
of Strengthening the character education values for students in the Industrial revolution 4.0 era. Then the author also uses synthesis analysis, namely by handling certain scientific objects by combining one understanding with another understanding, which in the end can be obtained knowledge that is new, namely the urgency of the library as an effort to reduce the Behaviour of students' deviations in school. The author also uses content analysis, namely research conducted on information documented in recordings, both images, sounds, writing and others. With this method scientific data analysis and processing will be carried out on the contents of the Method of Strengthening Character Education values for students in the Industrial Revolution 4.0 Era.

\section{DISCUSSION}

Strengthening Character Education values for students in the Industrial

\section{Revolution 4.0 Era}

\section{Definition of Character Education}

Character education can be understood as a characteristic that is rooted in a person's personality that can encourage to act, behave, say, and respond to something (Novan, 2013: 24-25). Character education as an effort to instill intelligence in thinking, appreciation in the form of attitudes, and experiences in the form of Behaviour that is in accordance with the noble values that become his identity, manifested in interactions with his Lord, himself, between people, and the environment (Zubaedi, 2015: 17).

Character education is all the efforts made by educators that affect the character of students to shape into a good person and to form ethics 
in accordance with existing rules. It is formed in a planned manner with conscious effort that does not come from accidental nature. The education of character is commendable, namely education that teaches, fosters, guides, and trains so that students have character, positive mental attitude, and morality (Moh Haitami Salim, 2001: 34) .

\section{Function of Character Education}

Some of the functions of character education include the following:
a. Developing the basic potential to be kind, think well, and behave well;
b. Strengthening and building multicultural national Behaviour;
c. Increasing the nation's competitive civilization in the world association.

\section{Purpose of Character Education}

Character education is basically aimed at forming a strong, competitive, noble, moral, tolerant, mutual cooperation, patriotic-spirited, dynamic-developing, science-oriented, and technology-oriented nation that is all imbued with priests and piety to God Almighty based on Pancasila (Daniyanto , 2015: 6)

\section{Pattern of Character Education}

The pattern of character education is a system of workings of education that is not only oriented towards cognitive aspects, but is more oriented to the process of fostering the potential that exists in students, developed through the habituation of good traits in the form of teaching good character values (Helmawati , 2016: 157). Character education teaches that each individual is trained so that he can maintain good qualities within himself (fitrah) so that the character will be strongly 
attached to training through education so that akhlaqul karimah will be formed.

Character education is education to shape one's personality through character training, the results of which can be seen in people's actual actions, namely good behaviour, honesty, responsibility, hard work and so on. Character education is an effort to instill certain characters as well as provide seeds so that students are able to grow their distinctive character while living their lives ( Bambang Q-Anees and Adang Hambali, 2008).

\section{Values of Character Education in Students}

In the implementation of character education (Daryanto: 2015), 18 values have been identified originating from religion, Pancasila, culture, and national education goals including the following:

\section{a. Religious}

Submissive attitude and Behaviour in doing religion teaching, the practice of religion tolerant of others, and live in harmony with other faiths. Religious is the process of binding back or can be said with tradition, a system that regulates the order of faith (belief) and worship of God Almighty and rules that relate to the association of humans and humans and their environment.

b. Honest

Behaviour that is based on efforts to make himself as a person who can always be trusted in words, actions, and work.

c. Tolerance

Attitudes and actions that respect differences in religion, ethnicity, ethnicity, opinions, attitudes, and actions of others that are different from him. 
d. Discipline

Actions that exhibit orderly Behaviour and comply with various rules and regulations.

e. Hard work

Behaviour that shows earnest effort in overcoming various learning barriers and assignments, and completing tasks as well as possible.

f. Creative

Think and do something to produce a new way or result from something you already have.

g. Independent

Attitudes and Behaviours that are not easily depending on others in completing tasks.

h. Democratic

The way of thinking, behaving, and acting that values the rights and obligations of himself and others.

i. Curiosity

Attitudes and actions that always try to find out more deeply and extensively from something that is learned, seen, and heard.

j. Spirit of nationality

A way of thinking, acting and having insight that places the interests of the nation and the state above self and group interests.

k. Love the country

How to think, act, and do that show of loyalty, care, and a high appreciation of language, physical environment, social, cultural, economic, and pol i tick nation. 
1. Appreciate Achievement

Attitudes and actions that encourage him to produce something that is useful for society, and acknowledge, and respect the success of others.

m. Friendly/Communicative

Actions that show pleasure in talking, socializing, and working with others.

n. Love peace

Attitudes, words, and actions that cause other people to feel happy and safe in their presence. Self, community, environment (natural, social and cultural), country.

o. Like to read

The habit of providing time to read various readings that provide virtue for him.

p. Environmental care

Attitudes and actions that always try to prevent damage to the surrounding natural environment, and develop efforts to repair natural damage that has already occurred.

q. Social care

Attitudes and actions that always want to provide assistance to other people and communities in need.

r. Responsible

The attitude and Behaviour of a person to carry out his duties and obligations, which he should do, to himself or others and the surrounding environment. 


\section{Industrial Revolution 4.0}

a. Definition of the Industrial Revolution 4.0.

The Industrial Revolution 4.0 was marked by the great advancement of computers. The progress of computers that were originally only translated as information tools and high-tech calculating tools became " exponential technologies". The industrial revolution 4.0 is a revolution that integrates the parallel effects of multi-exponent technology into a new force in life. The life exponents in question are: (1) Artificial Intelligence or artificial intelligence, (2) biotechnologies, and (3) nano materials. These three exponents are the latest technology resulting from the development of computer power that is encrypted into the latest technology which is very complex and nano ( Zaki Mubarak, 2018 ).

In the book Social Change and Education the life of the people and the State in the industrial revolution era 4.0. HAR Tilaar argues that the source of prosperity and strength no longer lies in the vast area and abundant natural resources but has moved to the mastery and utilization of science and technology. This is the new civilization of humanity. There are three dominant forces:

1) Science

2) Technology as the application of science

3) Information

These three forces are no longer directly related to nationality. Science does not need to cross national borders and therefore does not require passports and visas. Likewise information 
wafts everywhere without limits and nothing can stop or hinder (Tilaar, 2012: 47).

This is the era of information and science that provides new scenarios full of possibilities. These possibilities must be exploited in accordance with scientific progress. Information technology has changed the country's culture into a global culture because the barriers that isolate the lives of various global societies become very fast because there are no restrictions on space and time. As explained earlier, technological progress has shaken the joints of the nationstate. Technological progress has accelerated the process of globalization and demanded a realignment of human life in various aspects (Tilaar, 2012: 47).

b. Characteristic of the industrial revolution 4.0

There are at least four things that make the industrial revolution 4.0 very attractive to humans today. This was stated by Indonesian leader Reinald Kasali ( Mubarak, 2018: 17) :

1) Simple

Simple which means the industrial revolution 4.0 has strength in simplicity and anti-complexity. Easy is the buzzword of the industrial revolution 4.0, where everything changes because there is a convenience factor there.

2) Faster

Faster which means fast is one of the forces in the industrial revolution 4.0. the faster the service and presentation, then people are willing to leave the previous slow system. Everyone is generally 
happy with the speed factor because this element is considered as an anti-waiting response.

\section{3) Cheaper}

Cheaper, which means cheap financing. Access to technology that can only be used to reach the middle to the top, can now be reached by all people because it is cheap.

4) Accessible

Accessible which means it can be accessed. In the past, poor was defined by developmentalists as being two: poor money and poor access. Access is a new wealth through open and open access. Because access is a wealth, people will be happy to have good access.

\section{Educational Characteristics in Industrial Revolution 4.0 Era}

There are several dimensions that must be considered in understanding the industrial revolution 4.0:

a. Demographic Dimensions

Previously, education was limited by time and space as a limit. Schools can be placeless and timeless. That is, real places are replaced by unlimited virtual spaces, so there is no limit to learning time. Students can learn anytime, anywhere and with anyone.

b. Professional Dimension

In the previous era, the profession was well organized and had a high level of establishment (the result of past community consensus). In the Industrial revolution 4.0 era, there was a disruptive job where the type of work that was previously established is now considered irrelevant. This new work is related to the change and 
development of the digital world. The jobs must be prepared by educational institutions. Therefore, inevitably educational institutions must have a specific strategy in making links and matches between the concepts of education and work practices.

c. Literacy Dimension

Literacy is literacy which can be defined according to the type of thinking skills. LOTS ( Lower Order Thinking Skills) defines literacy by memorizing, understanding and applying. HOTS (Higher Order Thinking Skills) can define literacy by evaluating, analyzing and creating.

1) Data Literacy

Students are not only presented data (knowledge, information, material) with the nature of single reality (single truth) but must be multiple reality (plural truths). The subject matter is endless and easily accessible through the digital world and it must be an indisputable fact. Data that is used as subject matter must be able to be analyzed into useful and good knowledge for the lives of students.

2) Technology Literacy

Students in the 4.0 industrial revolution aim to understand the source of data through technological tools. Understanding how to work and maintenance is an absolute thing that must be known. This ability will help education become more rapidly developing. Productivity as the character of the industrial revolution 4.0 will be faster realized if they understand the 
working procedures of machine which is used as an important part of learning.

3) Human Literacy

Data and technology tools are something passive and can work according to the will of the user of his. Humans as a single user must understand the nature of his life and continue his future life. Human as social, political and cultural being cannot be separated from the dynamics of life which are varied.

\section{Method of Strengthening character education values for students in the}

\section{Industrial Revolution 4.0 era}

In strengthening the character education value in the Industrial Revolution Era, the position of educators / teachers occupying strategic positions must be supported by appropriate reinforcement methods including:

a. Exemplary Method

Exemplary education provided to students is the most influential method for students. Students first see, hear, and socialize with their parents and teachers at school. If parents and teachers as educators behave honestly, can be trusted, have noble character, are brave and keep away from deeds that are prohibited by religion, students will grow in honesty, be formed with noble morals, become brave learners, and be able to distance themselves from deeds that are forbidden by religion.

b. Pilot Method

Both parent and teacher educators are pilot figures. If parents say words of instruction to students, but students will carry out what they are told especially what they do not know if they are not given examples. For example, how students will worship if their parents do not give examples 
of how to pray it. In fact, many parents who ordered prayers to learners, while they themselves do not pray.

c. Habituation Method

Habituation is a condition in which a person applies Behaviours that have never been done or are rarely carried out so that they often become habits. Good habits such as worshiping God that children always carry out in the family will become habits for students as well.

d. Repetition Method

Repetition is an activity that is repeatedly done so that it becomes memorized, understood, or accustomed. The repetition method can be applied to the cognitive, affective and psychomotor stages of students. Examples of repetition in the cognitive level are memorization of subject matter at school. While the example for effective repetition is diligently giving alms to the poor with compassion. An example of psychomotor repetition is repetition done by a member of the body such as the procedure for prayer, gymnastics, or other hand skills.

e. Training Method

Training is practicing a theory that has been learned. Many things that if trained will produce tough characters and never give up on students. Examples of training that can be done in shaping the character of students include reading, writing, arithmetic, and skills training.

f. Motivation Method

Humans have a spirit that sometimes goes up and down, so when humans are in a condition of falling spirits he needs to be motivated. Humans have the potential that when motivated they will show better performance. Motivation provides a very good and positive 
impact on the development of human psychology, especially the development of student education.

g. Family environment conduciveness

Students who feel comfortable because harmony in the family will make an impact on comfort in school, then harmony is expected to eliminate the emotional distance between parents and students.

There are 10 ways to shape student character education in the family, namely :

1) Morality of Honour

Respect is the main key for humans to be able to live in society, especially in society, especially in a plural society. Respect must be given to yourself as a human being, that is to keep yourself from engaging in self-destructive Behaviour. Then respect for others as fellow human beings who are God's creations, even though they differ in ethnicity, religion, and outlook on life, that is, by not hurting fellow human beings physically or emotionally. Respect the environment for not hurting animals and plants and always protecting the environment.

Tolerance in the family and community is an attitude that must be applied to students because it will create complete happiness in the family. tolerance in the family will also eliminate jealousy and jealousy if one parent is more intense in instilling religious education in students.

2) The Development of Morality of Respect Gradually

Students cannot immediately become moral human beings, but need a continuous socialization process from their parents and the 
need to conduct socialization with the surrounding community so that students have broad knowledge and insight. Educating students requires a high level of patience, therefore it requires commitment from their parents. Society is very much needed in the cultivation of character education to students because it is within the community. Students will get character education that is not embedded in homes and schools when socializing with the surrounding community.

3) Teach the Principle of Mutual Respect

Students will learn how to respect others if they also feel respected. Parents should respect their students as humans even though they are still small. Ways of respecting parents given to their students for example provide disciplinary rules by teaching to discuss about rational reasons why there should be rules governed by speaking politely. Students need the attention of both parents in instilling character education. If one of the parents is less attentive, the learner is disrupted. Both parents must always play an active role in the development of character education of students so that the development of character education of students is not disrupted.

4) Teach by Example

A fairly effective way to teach students is to give concrete examples of how the Behaviour should be, even if it is not said directly. For example, by inviting students to pray together in congregation, or by reading a book that contains moral messages. 
5) Teach with Words

Besides the importance of teaching by example, it is also important to say what we model. Students need to be explained why calling friends with bad nicknames is not good, because it can damage people's trust. Teaching about aspects of religion and spirituality, for example, teach love of God, and love of God must be manifested in daily life, namely by doing good.

6) Encourage students to reflect on their actions

When students do something that is not good, students need to be encouraged to think about their actions and what the consequences can be. Parents should give encouragement, motivation, and enthusiasm to students because motivation and enthusiasm grow from themselves and are influenced from outside. himself. motivation and enthusiasm of parents to students will bring up a sense of enthusiasm and motivation of students in conducting character education instilled by parents.

7) Teaching Students to Carry Responsibilities

Students who have been given responsibility since childhood will develop into students who care about other people. Responsibilities that parents can teach by introducing social work outside the home, such as by inviting students to go to an orphanage to make a donation.

8) Balance between Freedom and Control

Parents must be able to be assertive in giving rules and want to listen to students' responses. Students are given the freedom to ask 
why he should do something, but parents do not just obey the wishes of students.

9) Love Learners

The basis of character building is love. Parent's love will contribute greatly to the formation of learners' character.

10) Creating a Happy Family Together

Character education and the effort to create a happy family are two sides of the same coin. Families must be able to manage conflict constructively, for example by using educated approaches including:

a) By fostering mutual understanding;

b) By finding joint solutions through deliberations agreed by the parties in conflict;

c) Following up on how joint agreements have been carried out, for example by evaluating (Zubaedi, 2015)

Challenges and opportunities faced in strengthening the value of character education in the Industrial Revolution 4.0 era

Challenges as well as opportunities for change and progress in education in Indonesia through strengthening the value of character education can be done with an integrative principle, where all elements forming the character of students work together synergistically in assessing the value of character education.

The main elements included in the challenge of strengthening the value of students' character education include several other elements including:

a. Readiness of educational institutions, educational institutions should not be an instrument that only gives broad technological space to control 
humans, it must be the other way around, humans control technology so that the strengthening of character education is absolutely carried out by all elements of education in an integrative way

b. Readiness of educator resources in providing value education for character education, currently a variety of learning innovations is a key condition for the development of learners' basic character, through learning innovation, it must be balanced with the quality and capabilities of educators

c. Family readiness as the main pillar of the character building of students and the main process in internalizing the value of character education in it

d. The still weak cooperation of all elements of society as a controller and supporter for the strengthening of the character education values of students.

e. The paradigm shift that initially positioned the technology product as a tool to help work productivity needs turned into a collective dependency for all levels of society. So that unnoticed and unconsciously begin to uproot the roots of the character education value of students to nonproductive activities that depend on technological and cultural products that were built in the Industrial revolution 4.0 era.

Opportunities obtained in strengthening the character education value for students in the Industrial Revolution 4.0 era.

Opportunity can be interpreted as an opportunity obtained when the crush of challenges arises, in the context of strengthening the character 
education value of students in the current period that has automatically followed and plunged into the development of the industrial revolution 4.0 has the opportunity to seize the opportunity as a character generation namely:

a. Opportunities are able to develop themselves more quickly through the help of existing information technology products

b. Being able to be an innovator in creating creation and technology advancement products through information sources that are easily available today

c. Learners from all walks of society have the same opportunity to strengthen its competitiveness in the global era.

So in responding to existing challenges, the use of opportunities through the advancement of technology and information flows has become a necessity that must be responded to wisely and balanced, to make it necessary to underline the limitations of opportunities that can be taken, among others:

a. Students are able to position themselves as intelligent and selective technology consumers

b. Information and technology products as a means of increasing student productivity are not addictive objects whose existence becomes merely an addictive without meaning

c. Learners must be wise both as users of technology products and social beings who require real socialization and clear verbal communication for development and sharpening of character psychology. 


\section{CONCLUSION}

Based on the explanation and description above, it can be concluded that: Methods of strengthening the character education value for students in Industrial Revolution 4.0 include: a) Modelling Methods, b) Pilot Methods, c) Customization Methods, d) Repetition Methods, e) Training Methods, f) Motivation Methods. Challenges and opportunities faced in strengthening the character education values in the Industrial Revolution 4.0 era are in the form of: a) Challenges faced in strengthening the value of character education in the Industrial Revolution 4.0 era, such as: 1) Readiness of educational institutions, 2) Readiness of educator resources in providing reinforcement of character education values, 3) Family readiness as the main pillar faced in strengthening character education values in the Industrial Revolution 4.0 era, 4) Weak control and support from elements of society, 5) Shifting the paradigm of curry society productivity into consumptive. Opportunities obtained in strengthening the character education values for students in the Industrial Revolution 4.0 era are such as: 1) Opportunities are able to develop themselves more quickly, 2) They are able to be an innovator in their field of expertise, 3) Students from all background have the same opportunity in strengthening competitiveness in the global era.

\section{REFERENCES}

Ahmadi, Rulam. (2016). Pengantar Pendidikan. Yogyakarta: Ar-Ruz Media. Damayanti, Deni. 2014, Panduan Implementasi Pendidikan Karakter Di Sekolah . Yogyakarta: Araska 
Attarbiyah, Journal of Islamic Culture and Education

https://www.attarbiyah.iainsalatiga.ac.id/index.php/attarbiyah/

Fathurrohman, Muhammad. (2015). Paradigma Pembelajaran Kurikulum 2013

Strategi Alternatif Pembelajaran di Era Global. Yogyakarta: Kalimedia.

Mubarak,Zaki. (2018). Pendidikan di Era Revolusi Industri 4.0 dan Problematika

Pendidikan Tinggi, Yogyakarta: Ganding Pustaka.

Q-Anees, Bambang dan Adang Hambali. (2008). Pendidikan Karakter berbasis Al-

Qur'an. Bandung: Simbiosa Rekatama Media.

Tilaar, H. A. R. (2012),Perubahan Sosial dan Pendidikan. Jakarta: PT Grasindo.

Wiyani, Novan Ardy. (2013). Membumikan Pendidikan Karakter Di SD Konsep, Praktik, dan Strategi. Jakarta: Ar-Ruz Media.

Zubaedi. (2015). Desain Pendidikan Karakter Konsepsi dan Aplikasinya dalam Lembaga Pendidikan. Jakarta: Prenada Media. 